\title{
Oral Biology and Dentistry

\section{Salivary inflammatory mediators and metalloproteinase 3 in patients with chronic severe periodontitis before and after periodontal phase I therapy}

\author{
Silvia Reina ${ }^{1,3}$, Fernando Hoyos ${ }^{2}$, Nelson Carranza ${ }^{2}$ and Enri Borda ${ }^{1,3^{*}}$ \\ *Correspondence: enri@farmaco.odon.uba.ar \\ 'Pharmacology Unit, School of Dentistry, University of Buenos Aires, Argentina. \\ ${ }^{2}$ Cátedra de Periodoncia, School of Dentistry, University of Buenos Aires, Argentina. \\ ${ }^{3}$ National Research Council of Argentina, Buenos Aires, Argentina.
}

\begin{abstract}
Background: The role of IL-1 $\beta$, PGE $_{2}$ and MMP-3 in the pathogenesis of periodontal disease is well researched. This study aimed to asses and compared the salivary IL- $1 \beta, \mathrm{PGE}_{2}$ and MMP-3 levels in patients with untreated chronic severe periodontitis and those treated with periodontal phase I therapy and periodontally healthy individuals as controls, in relationship to the presence of salivary anti- $\beta_{1} \operatorname{IgA}$.

Methods: A total of 30 subjects participate in the study: 15 subjects had chronic severe periodontitis and 15 were healthy individuals used as a control. After saliva collection and its purification, we quantify by enzyme-linked immunosorbent assay (ELISA) procedure using as coating antigen a synthetic $\beta_{1}$ peptide with an amino acid sequence identical to the second extracellular loop of the human $\beta$ adrenoceptor $\left(\beta_{1} \mathrm{AR}\right)$, the presence of anti $\beta_{1}$ AR antibody $(\operatorname{Ig} A)$ in the saliva of patients and healthy individuals. Also, IL-1 $\beta$, PGE, nitrites and metalloproteinase 3 (MMP-3) were assessed using ELISA) assay.

Results: Our data indicated that IL-1 $\beta$, PGE $_{2}$, nitrites and MMP-3 levels are elevated in the saliva of patients with untreated chronic severe periodontitis and were significantly higher than in healthy subjects. Also, the amounts of anti- $\beta_{1} \operatorname{IgA}$ in the saliva was significantly higher compared with that of healthy individuals. After periodontal phase I therapy these levels of inflammatory biomarkers are significantly reduced but the titres of the antibody did not change, suggesting a close association between salivary IL$1 \beta, \mathrm{PGE}_{2}$, nitrites and MMP-3 and periodontitis without any changes in the levels of anti $\beta_{1}$ IgA.

Conclusions: These results suggest that the abnormal amount of these cytokines and enzymes in saliva has potential monitoring applications as a risk marker of the disease progression but the raised levels of anti $\beta_{1}$ IgA present in the saliva of chronic severe periodontitis patient, are not directly associated with the course of the disease. Additional studies are needed to validate this assumption.
\end{abstract}

Keywords: Periodontitis, IL-1 $\beta, \mathrm{PGE}_{2}$, antibodies anti- $\beta_{1} \operatorname{IgA}$

\section{Introduction}

Periondontal disease is a chronic microbial and inflammatory process characterized by the presence of sulcular pathogenic bacteria, impaired host immune response, destruction of the connective tissue involved in tooth attachment, and resorption of alveolar bone. Bacterial pathogens are required to initiate the disease process [1-3].

Circulating substances have been detected at elevated levels in gingival crevicular fluid and whole saliva of patients who have periodontal disease, making them putative biomarkers of the disease [4-6]. Periodontal pathogens activate host cells to produce pro-inflammatory mediators $[7,8]$ and cytoplasmatic enzymes [9], which, in turn, promote the destruction of periodontal tissues. The release of the inflammatory cytokine, IL-1 $\beta$, PGE $_{2}$ and lysosomal and cytoplasmic enzymes, such as metalloproteinases (MMPs), to periodontal tissues is higher in the areas with inflammation [10,11]. In addition, various enzymes, cytokines and biomarkers of bone turnover have been found to be elevated in the saliva of periodontitis patients in comparison with periodontally healthy controls [12-14].

Recently, we reported that in the sera of periodontitis patients we found autoantibodies against atria cardiac $\beta_{1}$-adrenoreceptor (anti- $\beta_{1}-A R \operatorname{lgG}$ ) that were able to mimic the effect of an authentic $\beta_{1}-A R$ agonist acting on atria $\beta_{1}-A R[15,16]$. However, the release of host-derived inflammatory mediators, such as cytokines from chronically inflamed periodontal tissues, into the circulation together with the sera anti- $\beta_{1}-\mathrm{AR} \lg \mathrm{G}$, may provide a link between periodontal disease and cardiovascular disease $[17,18]$. Moreover, the effect of anti- $\beta_{1}-A R \lg G$ acting on $\beta_{1}-$ $A R$ in rat atria and its capacity to activate caspase pathway, molecular signals involved in anti- $\beta_{1}$-AR IgG - $\beta_{1}$-AR-stimulated myocardium apoptosis and increased CAMP production and JNK phosphorylation, and the role of anti- $\beta_{1}-A R \lg G$ in the release of inflammatory mediators ( $\mathrm{PGE}_{2}, \mathrm{NO}, \mathrm{cGMP}$ ) that participate in atria $\beta_{1}$-AR-stimulated cardiomyocytes apoptosis were also determined [19]. 
Reina et al. Oral Biology and Dentistry 2013,

http://www.hoajonline.com/journals/pdf/2053-5775-1-3.pdf

Table 1. Comparison of the Clinical Parameters of the CP patients with or without Conventional Periodontal Treatment.

\begin{tabular}{ll|ll}
\hline Characteristics & $\begin{array}{l}\text { Healthy subjects } \\
(\text { control })(\mathbf{n}=\mathbf{1 5})\end{array}$ & $\begin{array}{l}\text { Chronic Periodontitis Patients } \\
(\mathbf{n}=15)\end{array}$ & \\
\cline { 3 - 4 } & & $\begin{array}{l}\text { Before } \\
\text { Treatment }\end{array}$ & \multicolumn{1}{l}{$\begin{array}{l}\text { After } \\
\text { Treatment }\end{array}$} \\
\hline Age (years, SD) & $49.6 \pm 5.2$ & $47.9 \pm 5.6$ & $47.5 \pm 5.4$ \\
Male (\%) & 80 & 75 & 75 \\
Smoking & $0 / 12$ & $0 / 15$ & $0 / 15$ \\
(non-smoker/smoker) & & & \\
CAL $\geq 2$ mm (\%, SD) & 0 & $80.54 \pm 12.31$ & $60.33 \pm 11.16^{*}$ \\
PD $\geq 4$ (\%, SD) & 0 & $69.40 \pm 15.91$ & $47.96 \pm 17.71^{* *}$ \\
BOP (\%, SD) & $5.37 \pm 1.65$ & $88.44 \pm 10.76$ & $75.42 \pm 10.26$ \\
PI (SD) & $1.10 \pm 0.51$ & $6.14 \pm 0.48$ & $2.28 \pm 0.38^{* *}$ \\
GI (SD) & $0.55 \pm 0.25$ & $1.46 \pm 0.18$ & $1.40 \pm 0.21$ \\
\hline
\end{tabular}

All patients and healthy individuals had at least 20 teeth and no systemic diseases. Values expressed the means \pm SD of fifteen patients and fifteen healthy normal subjects. CP: chronic Periodontitis; CAL: clinical attachment level; PD: probing depth; BOP: bleeding on probing; PI: periodontal index; GI: gingival index; SD: standard desviation. Mann-Whitney U-test was applied and differences were considered statistically significant when $\mathrm{P}<0.05$. ${ }^{*} \mathrm{P}<0.001$ comparing $\mathrm{CP}$ after versus $\mathrm{CP}$ before treatment; ${ }^{\star \star} \mathrm{P}<0.001$ comparing $\mathrm{CP}$ after versus $\mathrm{CP}$ before treatment.

Based on these observations, we considered it of special relevance to investigate whether salivary secretory $\lg A$ (anti- $\beta$ $\lg A$ ) from patients with chronic severe periodontitis could be a new marker of the pathosiological event that occurs in this disease in relationship with host-derived enzymes (MMPs), cytokines (IL-1 $\beta$ ) and PGE 2 present in the saliva of the untreated periodontitis patients and those treated with periodontal phase I therapy in its.

\section{Materials and methods Patients}

The patients in this study were 40 to 60 year-old, non-smoker males being treated in the Department of Periodontics, School of Dentistry, University of Buenos Aires.

Thirty patients with pre-existing chronic severe periodontitis were included in the test group before and after conventional periodontal I therapy. The assessment of clinical parameters was carried out by a trained periodontist following criteria based on clinical parameters and the severity of periodontal tissue destruction [20]. The characteristic clinical signs of periodontitis included loss of clinical attachment, horizontal and/or angular alveolar bone loss, periodontal pocket formation, and gingival inflammation. To be included in the study, at least six sites with ongoing periodontal disease were required. Clinical measurements in patients with periodontitis included sites with alveolar bone loss $>2 \mathrm{~mm}$ and a pocket depth $>5 \mathrm{~mm}$ with bleeding and attachment loss $>3 \mathrm{~mm}$. No subject (periodontal patient or healthy individual) had any systemic illness and they were all never-smokers. Patients with periodontitis had not received periodontal treatment or antibiotics within the preceding 5 months or any anti-inflammatory drug within 3 weeks prior to the study. The clinical characteristics of the study population and the healthy subjects (controls) are shown in (Table 1).

The control group consisted of thirty healthy non-smoker volunter males of the same age range, and with a clinically healthy periodontium from the same department. In the healthy subjects (control group), the probing depth was $<3$ $\mathrm{mm}$ and the attachment loss was $<2 \mathrm{~mm}$. Moreover, probing pocket depth and clinical attachment level were assessed at six sites per tooth and bleeding on probing at four sites per tooth. This group had $<10 \%$ of sites with bleeding on probing (BOP), no sites with probing depth $(P D) \geq 4 \mathrm{~mm}$, no clinical attachment loss (AL), $<2 \mathrm{~mm}$, and no radiographic evidence of bone loss.

Exclusion criteria were individuals who had undergone periodontal treatment in the last 6 months; history of medications including antibiotics and anti-inflammatory drugs in the last 6 months; history of any systemic disease; and detection of any obvious oral mucosal lesion.

This study was approved by the Ethical Commission of the School of Dentistry, University of Buenos Aires. Written informed consent was obtained from each participant in this study, which was conducted under the rules of the Helsinki Declaration.

\section{Saliva collection}

Participants were instructed to refrain from eating, drinking and practicing oral hygiene procedures 12 hours before saliva collection. Whole unstimulated saliva was collected early morning after fasting ( 8 hours) from all patients by expectoration into sterile bulbs. The total amount of saliva collected was $1 \mathrm{ml}$. Collected samples were placed immediately on ice and transported to the laboratory, where they were centrifuged at 5,000 $\mathrm{g}$ for 10 minutes, and the clear supernatants were stored in aliquots at $-80^{\circ} \mathrm{C}$ in presence of protease inhibitors. The samples were thawed and the assays were performed with in 2 months of collection.

\section{Clinical parameters}

Clinical data included: CAL: clinical attachment level; PD: probing depth; BOP: bleeding on probing; PI: periodontal index; Gl: gingival index (Table 1). The index measurements were done at six sites per tooth (mesio-buccal, mid-buccal, disto-buccal, disto-lingual, mid-lingual and mesio-lingual) and CAL was obtained by measuring only interproximal sites. These data were recorded and the treatment was performed by a trained periodontist. The data were recorded after saliva sample collection.

\section{Periodontal therapy}

Periodontal phase I therapy (PPIT) consisted of full-mouth scaling, root planning and oral hygiene instructions. Only the patients with periodontitis received PPIT after saliva 
Reina et al. Oral Biology and Dentistry 2013,

Table 2. Salivary flow, total IgA and subclasses of IgA $\left(\operatorname{Ig} A_{1}\right.$ and $\left.\operatorname{Ig} A_{2}\right)$.

\begin{tabular}{lllll}
\hline Group & $\begin{array}{l}\text { Basal salivary } \\
\text { flow }(\mathbf{m l} / \mathbf{1 0} \text { min })\end{array}$ & $\begin{array}{l}\text { Total IgA } \\
(\mu \mathrm{g} / \mathbf{m l})\end{array}$ & $\begin{array}{l}\text { IgA }_{1} \\
(\mu \mathrm{g} / \mathbf{m l})\end{array}$ & IgA $_{2}(\mu \mathrm{g} / \mathbf{m l})$ \\
\hline $\begin{array}{l}\text { Periodontitis } \\
\text { patients }\end{array}$ & $1.2 \pm 0.6^{*}$ & $164 \pm 19$ & $66 \pm 5^{*}$ & $98 \pm 8^{*}$ \\
Healthy subjects & $9.7 \pm 3.5$ & $180 \pm 22$ & $72 \pm 6$ & $108 \pm 9$ \\
\hline
\end{tabular}

Values represent the means \pm SEM of 15 patients and 15 healthy normal subjects. ${ }^{\star} \mathrm{P}<0.0001$ comparing with healthy subjects.

sample collection and clinical measurements of baseline. The therapy was completed in two visits, each one week apart. No antibiotics were prescribed after the treatment. The patients were re-evaluated for clinical parameters one month afterwards and saliva samples were taken again.

\section{Purification of saliva IgA}

The IgA fractions of 15 patients with chronic periodontitis untreated and treated with PPIT and 15 healthy individuals were independently purified by standard diethylaminoethyl cellulose (DEAE) chromatography. Briefly, saliva samples were dialyzed against $0.01 \mathrm{M}$ phosphate buffer, $\mathrm{pH} 8.0$, for 18 hours and then applied to DEAE cellulose columns equilibrated in the same buffer. The pass-through IgG-rich fractions were discarded and IgA-rich fractions were eluted with $0.05 \mathrm{M} \mathrm{NaCl}$ in $0.01 \mathrm{M}$ phosphate buffer, $\mathrm{pH}$ 8. The IgA concentration in the enriched fractions was quantificated by radial immunodiffusion method after concentration by ultrafiltration with PM-30 filtering membranes (Amicon, Beverly, MA, USA) (cutoff molecular weight, $30,000 \mathrm{Da}$ ). The concentration of IgA was $35.8 \pm 15.2 \mathrm{mg} / \mathrm{dl}$ in the $\lg \mathrm{A}$-enriched fractions. IgA was also purified by affinity chromatography of different saliva on Jacalin agarose beads following the recommendations of the supplier (ICN Pharmaceuticals, Irvine, CA, USA) and previously described methods [21].

\section{ELISA procedure}

Fifty microliters of synthetic $\beta_{1}$ peptide solution $(20 \mu \mathrm{g} / \mathrm{ml})$ in $0.1 \mathrm{M} \mathrm{Na}_{2} \mathrm{CO}_{3}$ buffer, $\mathrm{pH}$ 9.6, was used to coat microtiter plates (NUNC, Kastrup, Denmark) at $4^{\circ} \mathrm{C}$ overnight.

After blocking the wells, diluted sera from patients with chronic severe periodontitis and healthy individuals (control) were added in triplicate and allowed to react with the peptide for 2 hours at $37^{\circ} \mathrm{C}$. After the wells were thoroughly washed with $0.05 \%$ Tween 20 in phosphate buffered solution (PBS) $100 \mu \mathrm{l}$ of 1:6000 biotinylated goat anti-human IgA antibodies (Sigma Chemical Co., St. Louis, MO, USA) was added and incubated for 1 hour at $37^{\circ} \mathrm{C}$. Then, a 1:6000 dilution of extravidin-alkaline phosphatase (Sigma) was allowed to react an extra 30 minutes at $37^{\circ} \mathrm{C}$. After extensive washings, p-nitrophenylphosphate $(1 \mathrm{mg} / \mathrm{ml})$ was added as the substrate, and the reaction was stopped at 30 minutes. Finally, the plates were read at $405 \mathrm{~nm}$ and the results for each sample were expressed as the means and SD of triplicate values.

\section{Biomarker analysis}

Concentration of salivary IL-1 $\beta(\mathrm{pg} / \mathrm{ml}), \mathrm{PGE}_{2}(\mathrm{ng} / \mathrm{ml})$, nitrites $(\mu \mathrm{M})$ and MMP-3 $(\mathrm{ng} / \mathrm{ml})$ were determined in duplicate using ELISA assay for each patient and the healthy individuals of the human colorimetric immunoreactive kits from Cayman Chemical (Ann Arbor, MI, USA), respectively.

\section{Drugs}

The synthetic $\beta_{1}$ peptide corresponded to the sequence of the second extracellular loop of the human $\beta_{1}-A R(H-W-W-R-$ A-E-S-D-E-A-R-R-C-Y-N-D-P-K-C-C-D-F-V-T-N-R-C) and a 27-mer non-related peptide S-G-S-G-S-G-S-G-S-G-S-G-S-G-S-G-S-GS-G-S-G-S-G-S-G-S, as a negative control, were synthesized by Peptide Genetic Research Company (Livermore, CA, USA) as described previously [22].

\section{Statistical analysis}

Student's $t$-test for unpaired values was used to determine the levels of significance. Analysis of variance (ANOVA) and a post hoc test (Dunnett's method and Student-Newman-Keuls test) were employed when pair-wise multiple comparison procedures were necessary. Differences between means were considered significant at $\mathrm{P}<0.05$.

\section{Results}

It can be seen in (Table 2 ) the total salivary $\lg \mathrm{A}$ (Total $\lg \mathrm{A}$ $(\mu \mathrm{g} / \mathrm{ml})$ in periodontitis patients: $164 \pm 19$; healthy subjects: $180 \pm 22 ; \mathrm{n}=15$ in each group) and its subtypes: $\lg \mathrm{A}_{1}(\mu \mathrm{g} /$ $\mathrm{ml}$ ): periodontitis patients: $66 \pm 5 *$; healthy subjects: $72 \pm 6$; ${ }^{*} \mathrm{P}<0.0001$ comparing with healthy subjects; $\mathrm{n}=15$ in each group and $\lg \mathrm{A}_{2}(\mu \mathrm{g} / \mathrm{ml})$ : periodontitis patients: $98 \pm 8^{*}$; healthy subjects: $108 \pm 9 ;{ }^{*} \mathrm{P}<0.0001$ comparing with healthy subjects; $\mathrm{n}=15$ in each group. Also, the values of the salivary flow (Basal salivary flow $(\mathrm{ml} / 10 \mathrm{~min}$ ) in periodontitis patients: $1.2 \pm 0.6 *$; healthy subjects: $9.7 \pm 3.5 ;{ }^{*} \mathrm{P}<0.0001$ comparing with healthy subjects; $\mathrm{n}=15$ in each group) were performed with commercial plates for radial immunodiffusion containing anti-lgA.

The distribution of anti- $\beta_{1}-A R \operatorname{Ig} A$ was studied in clarified human whole saliva (CHWS) from untreated chronic periodontitis patients, treated withPPIT chronic severe periodontitis patients and in healthy individuals (control). The scattergram of (Figure 1) shows that the optical density values (at $405 \mathrm{~nm}$ ) of salivary anti- $\beta_{1}-A R$ IgA from CHWS of the untreated chronic severe periodontitis patients (periodontal CHWS) and those from chronic severe periodontitis patients treated with PPIT. Also, the optical density values in healthy individuals (control CHWS) was shown. It can be seen that the data from periodontal CHWS and periodontal CHWS+PPIT were significantly higher $(\mathrm{P}<0.0001)$ than those of control CHWS. It is important to note that there is no significant difference between patients with chronic 


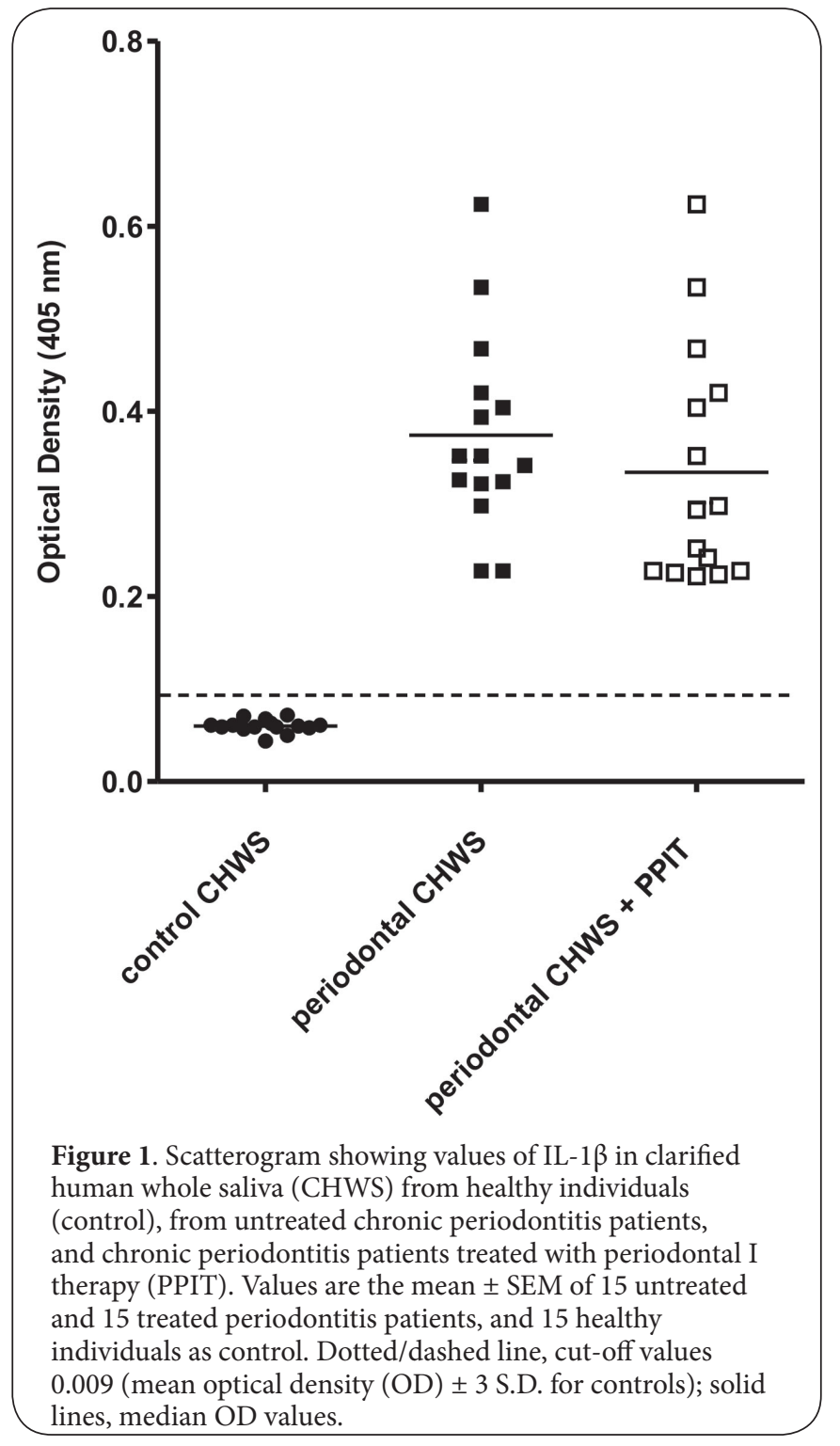

periodontitis before and after PPIT in the amount of this autoantibody. On the other hand, the immunoreactivity of saliva fron untrated and treated patients were negative in the presence of non-related peptide (data not shown), asserting the immunological recognition of the anti- $\beta_{1} A R \lg A$ salivary only when the coating antigen is the synthetic $\beta_{1}$ peptide.

(Figure 2) shows the distributions of $\mathrm{PGE}_{2}(\mathrm{~A})$ and nitrite (B) concentrations in CHWS from untreated patients, treated patients and healthy individuals. As shown in the scatterogram of (Figure 2A), $\mathrm{PGE}_{2}$ concentrations were significantly higher in chronic periodontitis patients than that in control CHWS $(\mathrm{P}<0.0001)$. Moreover, the concentration of $\mathrm{PGE}_{2}$ in $\mathrm{CHWS}$ from untreated chronic periodontitis patients was statistically significantly higher than that from treated patients $(P<0.001)$. It can be seen in (Figure 2B) that the concentration of nitrites
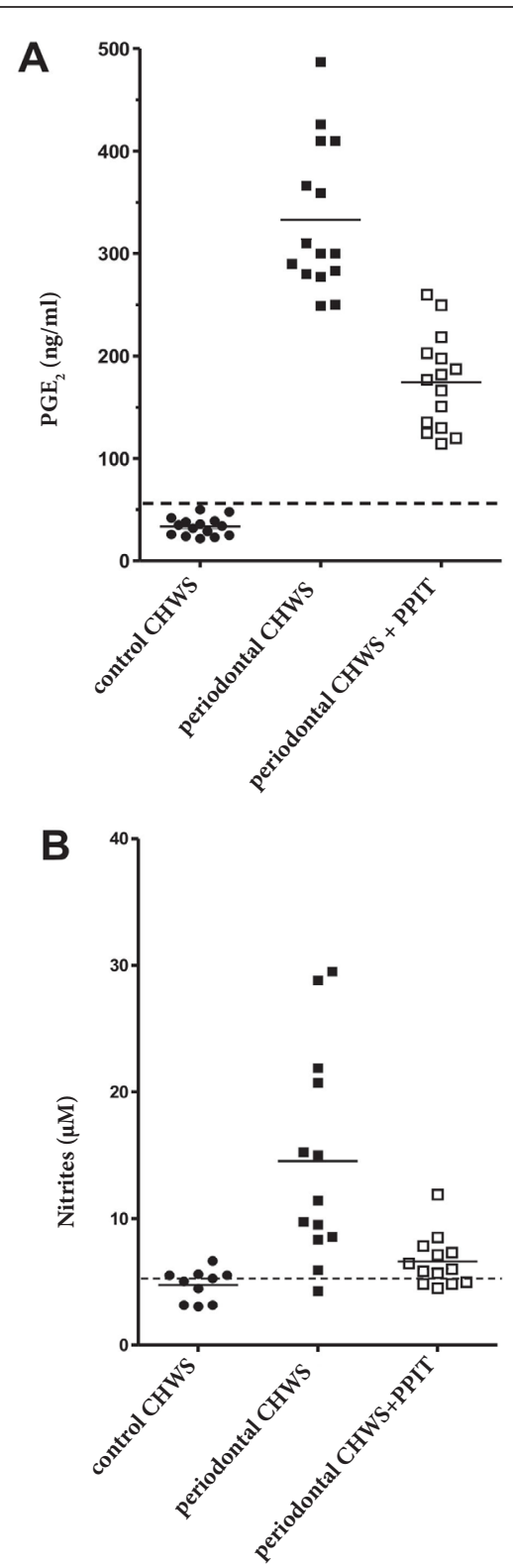

Figure 2. Scattergram showing values of $\mathrm{PGE}_{2}$ and nitrites in clarified human whole saliva (CHWS) from healthy individuals (control), from untreated chronic periodontitis patients, and chronic treated periodontitis patients. (A) Distribution of the values of PGE $(\mathrm{ng} / \mathrm{ml})$ in CHWS from healthy individuals (control), from untreated chronic periodontitis patients, and treated chronic periodontitis patients. (B) Distribution of the values of nitrites $(\mu \mathrm{M})$ in CHWS from healthy individuals (control) and from untreated chronic periodontitis patients, and treated chronic periodontitis patients. Values are mean \pm SEM of 15 untreated and 15 treated periodontitis patients and 15 healthy individuals as control. Dotted/dashed line, cutoff values of $53.8 \mathrm{ng} / \mathrm{ml}$ for $\mathrm{PGE}_{2}$; solid lines, median PGE 2 values; dotted/dashed line, cut off values of $6.01 \mu \mathrm{M}$ for nitrites; solid lines, median nitrite values. 


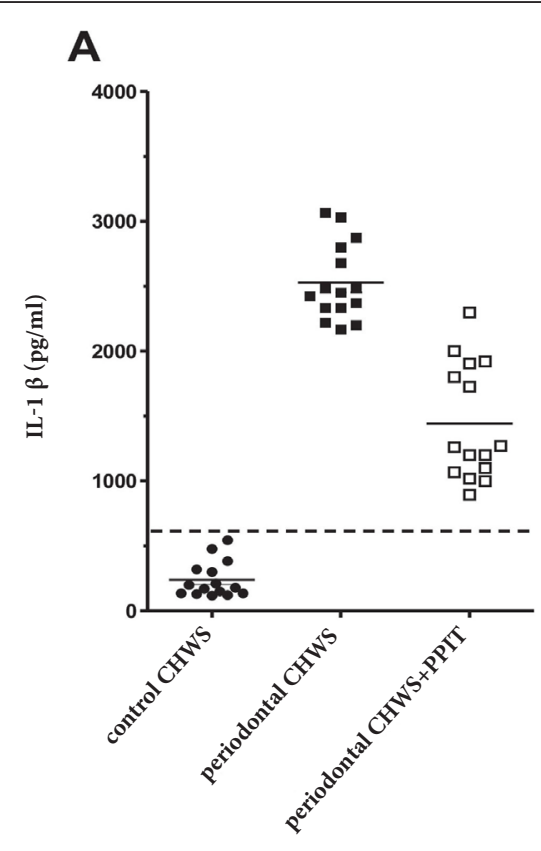

B

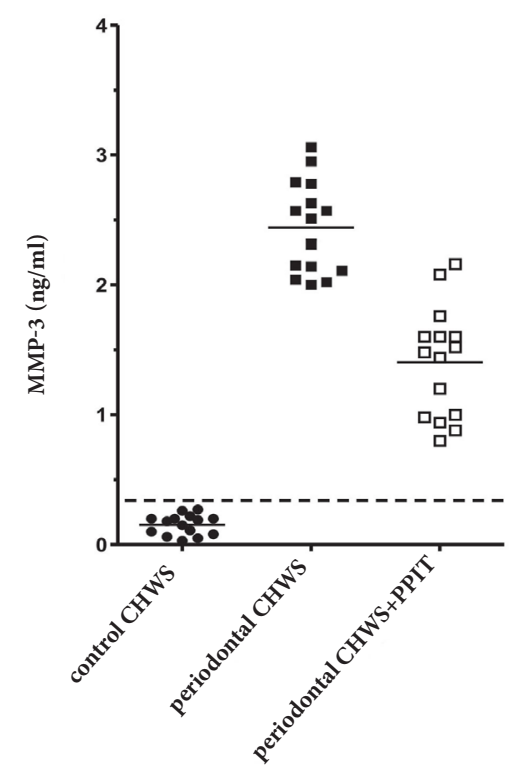

Figure 3. Scattergram showing values of IL-1 $\beta$ and MMP-3 in clarified human whole saliva (CHWS) from healthy individuals (control) and from untreated chronic periodontitis patients treated with periodontal I therapy (PPIT) chronic periodontitis patients. (A) Distribution of the values of IL- $1 \beta(\mathrm{pg} / \mathrm{ml})$ in CHWS from healthy individuals (control) and from untreated chronic periodontitis patients, and chronic periodontitis patients treated with PPIT. (B) Distribution of the values of MMP-3 (ng/ml) in CHWS from healthy individuals (control) and from untreated chronic periodontitis patients treated with PPIT chronic periodontitis patients. Values are the mean \pm SEM of 15 untreated and 15 treated periodontitis patients and 15 healthy individuals as control. Dotted/dashed line, cutoff values of $610.9 \mathrm{pg} / \mathrm{ml}$ for IL- $1 \beta$ and solid lines; median IL- $1 \beta$ values; dotted/dashed line, cutoff values of $0.25 \mathrm{ng} / \mathrm{ml}$ for MMP-3; solid lines, median, MMP-3 values.
Table 3. Mean values of the proinflammatory substances in whole human saliva.

\begin{tabular}{lllll}
\hline Groups & $\begin{array}{l}\text { anti- } \boldsymbol{\beta}_{1} \text { IgA } \\
(\mathbf{O D} 405 \mathbf{~ n m})\end{array}$ & PGE $_{2}(\mathbf{n g} / \mathbf{m l})$ & IL-1 $\beta(\mathbf{p g} / \mathbf{m l})$ & $\begin{array}{l}\text { MMP-3 } \\
(\mathbf{n g} / \mathbf{m l})\end{array}$ \\
\hline $\begin{array}{l}\text { Healthy } \\
\text { subjects }\end{array}$ & $0.060 \pm 0,001$ & $33.53 \pm 2,28$ & $237.90 \pm 35,34$ & $0.153 \pm 0,019$ \\
$\begin{array}{l}\text { Untreated } \\
\text { periodontitis } \\
\text { patients }\end{array}$ & $0.374 \pm 0,027^{*}$ & $333.12 \pm 18,64^{*}$ & $2528.00 \pm 76,01^{*}$ & $2.442 \pm 0,09^{*}$ \\
$\begin{array}{l}\text { Treated } \\
\text { periodontitis } \\
\text { patients }\end{array}$ & $0.353 \pm 0.026$ & $174.4 \pm 12.04^{*}$ & $1444.00 \pm 80.02^{*}$ & $1.402 \pm 0.12^{*}$ \\
\hline
\end{tabular}

Values expressed the means \pm SEM of fifteen patients and fifteen healthy normal subjects. ${ }^{\star} \mathrm{P}<0.0001$ comparing with healthy subjects.

in untreated patients were significantly increased when compared with control CHWS $(\mathrm{P}<0.0001)$ and the treated chronic periodontitis CHWS $(\mathrm{P}<0.001)$. The nitrite concentration from treated chronic periodontitis CHWS was not significantly different from that in the control group $(P>0.05)$.

It can be seen in (Figure $3 \mathrm{~A}$ ) that the concentration of IL-1 $\beta$ in CHWS from untreated patients and patients treated with HBPT, the concentration was significantly higher that in normal individuals. Again, the levels of this cytokine in treated CHWS were significantly different from that in untreated patients.

We next investigated the level of MMP-3 in CHWS from the three different groups. Significant values were obtained in untreated and treated chronic periodontitis patients compared to healthy subjects $(P<0.0001)$. Again, as shown above, MMP-3 levels in untreated and treated chronic periodontitis patients were significantly different $(\mathrm{P}<0.001$; (Figure 3B).

All of these findings are summarized in (Table 3 ), consistently indicating that the mean values of the different proinflammatory substances were significantly reduced after periodontal phase I therapy. But, the amount of anti- $\beta_{1}-A R$ IgA was not significantly different between untreated and treated chronic severe periodontitis patients.

(Figure 4) shows a positive correlation $(r=0.05)$ between the increment of $\mathrm{PGE}_{2}$ production and MMP-3 concentrations in the function of the presence in the saliva of the anti- $\beta_{1}-A R$.

\section{Discussion}

The fair amount is known about the immunological mechanisms responsible for the pathology observed in the disease. The morphology of chronic periodontitis lesions, and the clinical signs and symptoms of the disease suggest that cytokines (IL-1 $\beta$, PGE $_{2}$ ) [23,24], nitric oxide levels [25] and cytoplasmic enzymes (MMP-3) [26] are important in the pathogenesis of the disorders. But, we considerer important to determine if the anti $\beta_{1}$ adrenoceptor IgA present in the saliva of chronic severe patients, participates in the pathophysiology of the disease.

In this study we demonstrated high concentrations of IL- 
Reina et al. Oral Biology and Dentistry 2013,

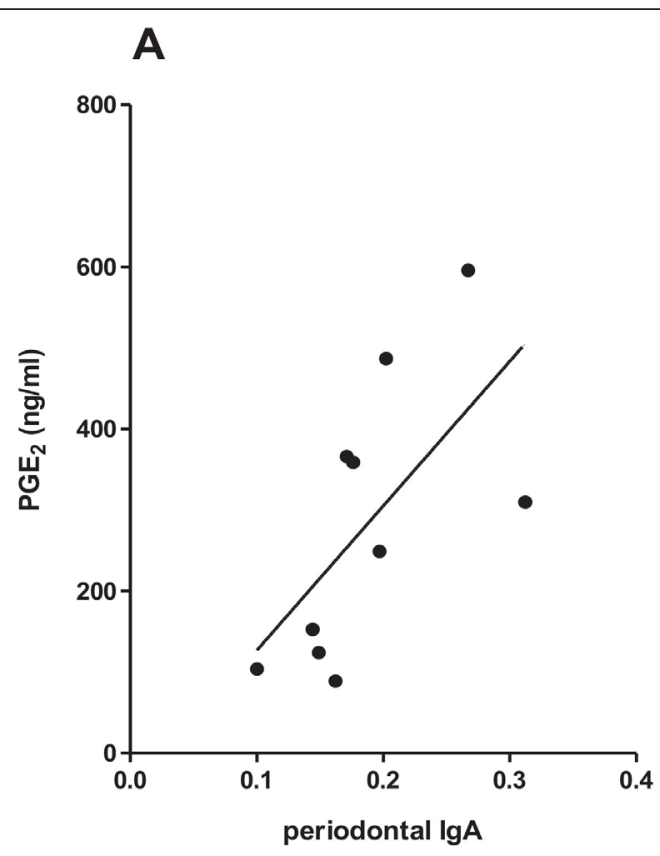

B

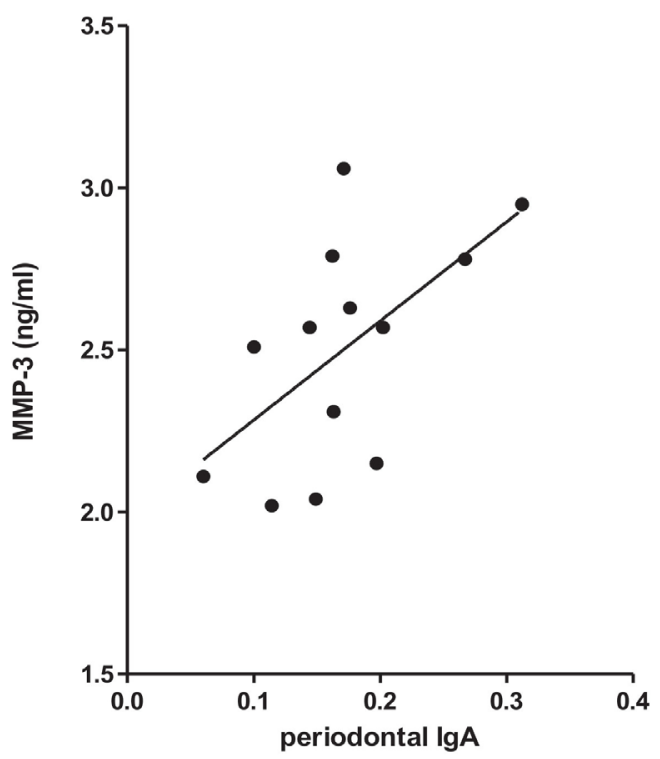

Figure 4. Correlation between the values of salivary anti- $\beta-R$

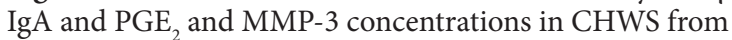
untreated chronic periodontitis patients.

$1 \beta, \mathrm{PGE}_{2}$, nitrites and MMP- 3 in saliva from untreated chronic severe periodontitis patients. Moreover, the highest levels of IL-1 $\beta$ and $\mathrm{PGE}_{2}$ were found in the saliva of these patients compared with those detected in healthy individuals (control). Previously was demonstrated that in human gingival fibroblasts are able to produce large amounts of $\mathrm{PGE}_{2}$ in response to inflammatory cytokines, and the increased $\mathrm{PGE}_{2}$ would be a potent stimulator of bone resorption [27]. Macrophages, mononuclear cells and fibroblasts from gingival tissues and endothelial cells are responsible for the increase in IL-1 $\beta$ production [28]; thus, there is a close association between IL-1 $\beta$ levels and periodontal disease status. After periodontal based therapy in patients with chronic periodontitis, IL-1 $\beta$ levels are reduced in all patients tested, which is correlated with clinical improvement. $\mathrm{PGE}_{2}$ is thought to be involved in the pathogenesis of the oral lesions observed in untreated chronic periodontitis, because of its role as a potent stimulator of bone resorption and association with attachment loss was published [29]. Therefore, there is a reciprocal interaction between $P G E_{2}$ and IL-1 $\beta$; IL-1 $\beta$ is a potent stimulator of $P G_{2}$ production in human gingival fibroblasts. However, $\mathrm{PGE}_{2}$ differential regulates IL-1 $\beta$-induced matrix metalloproteinase (MMP-3) production. In human gingival fibroblasts from healthy gingiva, $\mathrm{PGE}_{2}$ down-regulates IL-1 $\beta$-induced MMP-3 production, whereas in human gingival fibroblasts from periodontitis patients, $\mathrm{PGE}_{2}$ enhances it [29]. These data may reflect the heterogeneity of immuno-inflammatory responses in healthy and disease conditions, in which the concentrations of IL-1 $\beta$, PGE $_{2}$ MMP [30-31] may play a critical role as a marker of chronic severe periodontitis disease progression and oral manifestations.

The correlation between the amount of $\mathrm{PGE}_{2}$ and MMP-3 in the saliva of each patient studied in this study has demonstrated an important relationship with the amount of anti- $\beta_{1}$ $\lg \mathrm{A}$. Analysis of this result, $\mathrm{PGE}_{2}$ and MMP-3 performer on follow up studies underlines the correlation on the levels of the cytokine and the enzyme in the saliva of untreated patients with chronic periodontitis and the presence of salivary anti- $\beta_{1} \lg A$. It is important to note that, as previously reported, the pathogenesis of periodontal disease involves essential immunologic factors associated with infections caused by bacteria in sub-gingival plaques. The level of nitrite in saliva and its increment in patients with untreated chronic periodontitis was observed, and also an increased expression of iNOS in periodontal disease biopsy samples as well as in gingival fibroblast cell culture was described [22,32]. NO levels are associated with the severity of periodontitis, allowing differentiation between moderate and advanced generalized chronic periodontitis and NO levels were correlated with probing depth [25].

The biological plausibility of the differences observed in this study indicated that nitric oxide levels may be important in the pathogenesis of the disorders, and may be only in partly explained, by periodontal bacterial components triggering the host-immune response and causing inflammation and activation of pro-inflammatory mediators (IL- $1 \beta, \mathrm{PGE}_{2}$ and MMP-3). All of these molecules travelling in blood, together with those produced locally by the inflammatory process in the soft and hard oral tissues, might influence the pathophysiology of chronic periodontitis, but the real importance of the presence in the saliva of an anti $\beta_{1}$ adrenoceptor IgA remain to be determined. 
Reina et al. Oral Biology and Dentistry 2013,

\section{Conclusions}

The findings of the markedly elevated salivary IL-1 $\beta, \mathrm{PGE}_{2}$ and MMP-3 levels and their significant reduction post therapy in patients with chronic periodontitis compared to healthy individuals (control), suggest a close association between salivary cytokines and enzymes and the periodontal status. But, the real participation of an anti $\beta_{1}$ adrenoceptor $\lg A$ present in the saliva of patients with severe chronic periodontitis, incorporated another pathophysiological factor in this multifactorial disease was not clarified yet in this present work. Future longitudinal studies with larger sample sizes are needed to validate in saliva not only if IL-1 $\beta, P G E_{2}$ and MMP-3 are "real biomarkers" for periodontal disease but to know what role would play the autoantibody ( $\beta_{1}$ adrenoceptor $\lg A$ ) present in the saliva of these patients in the course of the periodontal disease or in its pathophysiology.

\section{Competing interests}

The authors declare that they have no competing interests.

\section{Authors' contributions}

\begin{tabular}{|l|c|c|c|c|}
\hline Authors' contributions & SR & FH & NC & EB \\
\hline Research concept and design & -- & -- & -- & $\checkmark$ \\
\hline Collection and/or assembly of data & -- & $\checkmark$ & $\checkmark$ & -- \\
\hline Data analysis and interpretation & $\checkmark$ & -- & -- & -- \\
\hline Writing the article & -- & -- & -- & $\checkmark$ \\
\hline Critical revision of the article & -- & -- & -- & $\checkmark$ \\
\hline Final approval of article & -- & -- & -- & $\checkmark$ \\
\hline Statistical analysis & $\checkmark$ & -- & -- & -- \\
\hline
\end{tabular}

Acknowledgement and funding

This work was supported by grant from Buenos Aires University (Grant number UBACyT 2011-2014). We thank Mrs. Elvita Vannucchi and Mr. Alejandro Thorton for their expert technical assistance.

\section{Publication history}

Editors: William Papaioannou, University of Athens Dental School, Greece.

Rory Munro Watt, University of Hong Kong, Hong Kong. EIC:Thimios A. Mitsiadis, University of Zurich, Switzerland. Received: 16-Sep-2013 Revised: 13-Nov-2013 Accepted: 28-Nov-2013 Published: 09-Dec-2013

\section{References}

1. Delima AJ, Karatzas S, Amar S and Graves DT. Inflammation and tissue loss caused by periodontal pathogens is reduced by interleukin-1 antagonists. J Infect Dis. 2002; 186:511-6. I Article | PubMed

2. Dennison DK and Van Dyke TE. The acute inflammatory response and the role of phagocytic cells in periodontal health and disease. Periodontol 2000. 1997; 14:54-78. I Article | PubMed

3. Deo $\mathrm{V}$ and Bhongade ML. Pathogenesis of periodontitis: role of cytokines in host response. Dent Today. 2010; 29:60-2; quiz 68-9. I Article | PubMed

4. Boch JA, Wara-aswapati $\mathrm{N}$ and Auron PE. Interleukin 1 signal transduction--current concepts and relevance to periodontitis. J Dent Res. 2001; 80:400-7. | Article | PubMed

5. Fujita $\mathrm{Y}$, Ito $\mathrm{H}$, Sekino $\mathrm{S}$ and Numabe $\mathrm{Y}$. Correlations between pentraxin $\mathbf{3}$ or cytokine levels in gingival crevicular fluid and clinical parameters of chronic periodontitis. Odontology. 2012; 100:215-21. | $\underline{\text { Article | PubMed }}$

6. Souza PP and Lerner UH. The role of cytokines in inflammatory bone loss. Immunol Invest. 2013; 42:555-622. | Article I PubMed

7. Silva N, Dutzan N, Hernandez M, Dezerega A, Rivera O, Aguillon JC, Aravena O, Lastres P, Pozo P, Vernal R and Gamonal J. Characterization of progressive periodontal lesions in chronic periodontitis patients: levels of chemokines, cytokines, matrix metalloproteinase-13, periodontal pathogens and inflammatory cells. J Clin Periodontol. 2008; 35:206-14. | Article I PubMed

8. Dogi CA, Weill F and Perdigon G. Immune response of non-pathogenic $\operatorname{gram}(+)$ and gram(-) bacteria in inductive sites of the intestinal mucosa study of the pathway of signaling involved. Immunobiology. 2010; 215:60-9. | Article | PubMed

9. Correa FO, Goncalves D, Figueredo CM, Gustafsson A and Orrico SR. The short-term effectiveness of non-surgical treatment in reducing levels of interleukin-1beta and proteases in gingival crevicular fluid from patients with type 2 diabetes mellitus and chronic periodontitis. $J$ Periodontol. 2008; 79:2143-50. | Article | PubMed

10. Offenbacher S. Periodontal diseases: pathogenesis. Ann Periodontol. 1996; 1:821-878. I Article

11. Miller CS, King CP, Jr., Langub MC, Kryscio RJ and Thomas MV. Salivary biomarkers of existing periodontal disease: a cross-sectional study. $J$ Am Dent Assoc. 2006; 137:322-9. | Article I PubMed

12. Kinney JS, Ramseier CA and Giannobile WV. Oral fluid-based biomarkers of alveolar bone loss in periodontitis. Ann N Y Acad Sci. 2007; 1098:23051. | Article | PubMed Abstract | PubMed Full Text

13. Tobon-Arroyave SI, Jaramillo-Gonzalez PE and Isaza-Guzman DM. Correlation between salivary IL-1beta levels and periodontal clinical status. Arch Oral Biol. 2008; 53:346-52. | Article | PubMed

14. Kaufman $E$ and Lamster IB. Analysis of saliva for periodontal diagnosis-a review. J Clin Periodontol. 2000; 27:453-65. | Article I PubMed

15. Segovia M, Ganzinelli S, Reina S, Borda E and Sterin-Borda L. Role of antibeta1 adrenergic antibodies from patients with periodontitis in cardiac dysfunction. J Oral Pathol Med. 2012; 41:242-8. | Article I PubMed

16. Segovia M, Reina S, Borda E and Sterin-Borda L. Autoantibodies to the beta(1)-Adrenoceptor from Patients with Periodontitis as a Risk Factor for Cardiac Dysfunction. ISRN Dent. 2011; 2011:791393. | Article | PubMed Abstract | PubMed Full Text

17. Espinola-Klein C, Rupprecht HJ, Blankenberg S, Bickel C, Kopp H, Rippin G, Victor A, Hafner G, Schlumberger W and Meyer J. Impact of infectious burden on extent and long-term prognosis of atherosclerosis. Circulation. 2002; 105:15-21. | Article | PubMed

18. Desvarieux M, Demmer RT, Rundek T, Boden-Albala B, Jacobs DR, Jr., Sacco RL and Papapanou PN. Periodontal microbiota and carotid intimamedia thickness: the Oral Infections and Vascular Disease Epidemiology Study (INVEST). Circulation. 2005; 111:576-82. I Article I PubMed Abstract | PubMed Full Text

19. Reina S, Ganzinelli S, Sterin-Borda L and Borda E. Pro-apoptotic effect of anti-beta1-adrenergic receptor antibodies in periodontitis patients. Int Immunopharmacol. 2012; 14:710-21. | Article | PubMed

20. Page RC and Eke PI. Case definitions for use in population-based surveillance of periodontitis. J Periodontol. 2007; 78:1387-99. | Article I PubMed

21. Roque-Barreira MC and Campos-Neto A. Jacalin: an IgA-binding lectin. J Immunol. 1985; 134:1740-3. I Article I PubMed

22. Sterin-Borda L, Furlan C and Borda E. Circulating beta(1) Adrenergic Autoantibodies from Patients with Chronic Periodontitis Interact with Gingival Fibroblasts. Eur J Dent. 2009; 3:191-9. | PubMed Abstract | PubMed Full Text

23. Kaushik R, Yeltiwar RK and Pushpanshu K. Salivary interleukin1beta levels in patients with chronic periodontitis before and after periodontal phase I therapy and healthy controls: a case-control study. J Periodontol. 2011; 82:1353-9. | Article | PubMed

24. Rausch-Fan X, Ulm C, Jensen-Jarolim E, Schedle A, Boltz-Nitulescu G, Rausch WD and Matejka M. Interleukin-1beta-induced prostaglandin 
Reina et al. Oral Biology and Dentistry 2013,

http://www.hoajonline.com/journals/pdf/2053-5775-1-3.pdf

E2 production by human gingival fibroblasts is upregulated by glycine. $J$ Periodontol. 2005; 76:1182-8. | Article | PubMed

25. Reher VG, Zenobio EG, Costa FO, Reher P and Soares RV. Nitric oxide levels in saliva increase with severity of chronic periodontitis. J Oral Sci. 2007; 49:271-6. | Article | PubMed

26. Ruwanpura SM, Noguchi K and Ishikawa I. Prostaglandin E2 regulates interleukin-1beta-induced matrix metalloproteinase-3 production in human gingival fibroblasts. J Dent Res. 2004; 83:260-5. | Article | PubMed

27. Scannapieco FA, Ng P, Hovey K, Hausmann E, Hutson A and WactawskiWende J. Salivary biomarkers associated with alveolar bone loss. Ann N Y Acad Sci. 2007; 1098:496-7. | Article | PubMed Abstract | PubMed Full Text

28. Gamonal J, Acevedo A, Bascones $A$, Jorge $O$ and Silva A. Levels of interleukin-1 beta, -8 , and -10 and RANTES in gingival crevicular fluid and cell populations in adult periodontitis patients and the effect of periodontal treatment. J Periodontol. 2000; 71:1535-45. | Article | PubMed

29. Khiste SV, Ranganath V, Nichani AS and Rajani V. Critical analysis of biomarkers in the current periodontal practice. J Indian Soc Periodontol. 2011; 15:104-10. | Article | PubMed Abstract | PubMed Full Text

30. Sanchez GA, Miozza VA, Delgado A and Busch L. Salivary IL-1beta and PGE2 as biomarkers of periodontal status, before and after periodontal treatment. J Clin Periodontol. 2013; 40:1112-7. | Article | PubMed

31. Kaushik R, Yeltiwar RK and Pushpanshu K. Salivary interleukin1 beta levels in patients with chronic periodontitis before and after periodontal phase I therapy and healthy controls: a case-control study. J Periodontol. 2011; 82:1353-9. | Article | PubMed

32. Kendall HK, Haase HR, Li H, Xiao Y and Bartold PM. Nitric oxide synthase type-Il is synthesized by human gingival tissue and cultured human gingival fibroblasts. J Periodontal Res. 2000; 35:194-200. | Article | PubMed

\section{Citation}

Reina S, Hoyos F, Carranza N and Borda E. Salivary inflammatory mediators and metalloproteinase 3 in patients with chronic severe periodontitis before and after periodontal phase I therapy. Oral Biol Dent. 2013; $1: 3$ http://dx.doi.org/10.7243/2053-5775-1-3 